\title{
LEGAL CHALLENGES IN REGULATION OF MINIMUM AGE OF CRIMINAL RESPONSIBILITY WITH SPECIAL EMPHASIS ON BOSNIA AND HERZEGOVINA
}

\author{
Goran Šimić \\ International University of Sarajevo \\ Ena Kazić \\ International University of Sarajevo
}

\begin{abstract}
Every minor can commit a criminal act, but in formal sense not every minor will be criminally responsible. Even if committing an act that in material sense have its consequences and all objective elements of a crime, possibility for imposing of criminal sanctions is still determined by minimum age of criminal responsibility (MACR). When reaching into certain age minors are held to be criminally responsible and punishable. This article is focusing to the matter of establishment of minimum age of criminal responsibility, so comparative review of systems for its establishment and contemporary world tendencies will be discussed in it. In particular, this paper will be devoted to the establishment of MACR in Bosnia and Herzegovina from both historical and positive law insight. The age from which one will be held criminally responsible is an issue predisposed by several factors and choosing the optimum age will be discussed as the challenging question in this paper because it includes or excludes minors from the reach of criminal justice system that has unquestionable impact in their future life.
\end{abstract}

Keywords: Minimum age of criminal responsibility (MACR), juveniles, criminal responsibility, punishability.

\section{Introduction}

Legal status of a minor and its legal responsibilities are topic relevant for all branches of law. But minors are big challenge especially for Criminal Law, since their inclusion into Criminal Law and reaction of a state to their entrance in the criminal zone can have big influence on them and their future life. Criminal sanctions bring legal consequences that as a shadow follows a person through the life, even when the "debt towards the society" is repaid with the served legal sanction.

Theorists agree that criminal responsibility should be imposed on individuals who have the capacity and freedom to choose how they act (Elliott, 2011, p. 289). Minors are not fully psychologically nor physically mature. Because of that it is assumed that they don't know what would be the best for them to do or which choice is the best one to make. This shows that their autonomy in choice of acts is limited and their capacity lacked. Moreover, according to Elliot (2011, p. 297) a strong relation between bad parenting, poverty, abuse and youth offending, which confirms weakness of their autonomy, has been scientifically proven. Yet, minors can perpetrate crimes, even in very cruel way, and society couldn't ignore that fact. Naturally, it had to be decided whether minors would be included in criminal law system; if yes, what age limit of criminal responsibility would be the most appropriable and finally, what would it be the best form of states' reaction to their offences. According to Griss et al. minors don't display the ability to act as adults, especially when it comes to unfamiliar situation such is crime or criminal procedure (Bryan-Hancock and 
Casey, 2011, p.72). Adults and children have significant psychological differences so that fact hasn't been mischarged when it was decided about inclusion of children in juvenile justice system. In contemporary Criminal Law, children are treated separately from adults, so that dual criminal law system has been created when determining legal status of perpetrator according to ones age.

Since minors are included in justice system it's crucial to establish the border from which is a person (who is not fully mature) criminally responsible or under which person who commits an act of crime is absolutely incapable of being guilty.

\section{Contemporary tendencies regarding establishment of minimum age limit of criminal responsibility}

It had been always very delicate question how to establish minimum age limit of criminal responsibility, since the main subject in the decision is a minor. According to Cipriani (2009, p. 94), the matter of limit of age responsibility is a matter of limit beneath which no treatment or penalty can be applied by law. If the limit would be set too high, then significant number of youth who was perhaps perfectly mature and aware of acts, just for not formally reaching specified number of ages, would lack with subjective element of crime and so would not be responsible for act that has all its objective elements and so finally they would be excluded from the punitive system. In other hand, setting the limit too low would include wide number of youth into punitive system, even though they could have grow out of crime and become useful and responsible members of society, without carrying the label of a convicted juvenile delinquent. And finally, it is important to question how convenient is it to establish a minimum age of criminal responsibility since matter of maturity is an individually predisposed and fluid process that is not always equivalent to chronological age (Bryan-Hancock and Casey, 2011, p. 72). Fried and Reppuccia proved in their research a fact that makes the process of establishment of MACR even more challenging: the lowest level of maturity wasn't found within young people of age 13-18, but of those from 15-16 years of age (see Bryan-Hancock and Casey, 2011, p. 72).

Having all that in mind, in contemporary criminal law there are several models of MACR that are applicable: determination of MACR as praesumptio ius et de iuris, determination of MACR as preasumptio iuris and specific general establishment of MACR in Sheria Law.

Indisputable presumption of criminal (ir)responsibility (praesumptio ius et de iuris) is applied in the most of countries of the world, especially of continental legal system. The idea was to set the minimum age (under which that person is considered to be a child and without any doubt or dispute considered not able to be guilty) and maximum age limit after which that person is to be treated as adult. If that person reaches certain age* in the moment of perpetration of a crime, then that person before law is adolescent and would be criminally responsible (otherwise could not be proven). Yet, the choice of criminal sanctions is much different from those that are to be imposed to adult.

This concept is well explained by Čejović stating that persons under MACR are not able to understand the significance of their actions and to coordinate with them, so the committed act isn't result of their asocial attitude but a result of lack of the control (Škulić,

\footnotetext{
* In 2010, Škulić finds that even the last day of the period of age before the minimum limit is considered to be criminally irresponsible and gives an example of decision of Supreme Court of Serbia, who decided that on the day of birthday of reaching 14 years that person is treated as still not having legal responsibility.
} 
2010 , p. 209). That gives us the reason why they shouldn't be punished and reached into criminal justice system.

MACR as praesumptio iuris of criminal responsibility is mostly spread in Common Law system. The MACR is given but maturity and criminal responsibility of persons over the minimum (until certain age) is disputable legal presumption, so in the criminal procedure the opposite can be proven. This presumption is more known as "doli incapax" doctrine. According to Howard and Bowen (2011, p. 381), it is used as a defence ,to a criminal charge for children within a certain age group coupled with a rebuttable presumption that such children were incapable of committing an offence“. The threshold of MACR in common law system is the most often 10 years of age and this doctrine is applicable until the age of 13. So, to found one minor (aged from minimum age of criminal responsibility to 13 years of age) guilty, it has to be proven that the accused juvenile was able at the relevant time to differ right from wrong, or to understand their acts of omissions being wrong (Richards, 2011, p. 5). That means that it is on the prosecution to prove if the child was fully capable and aware of the serious nature of their actions. In the practice, sometimes it can be very difficult to prove ones maturity, and for that reason some theoreticians and practitioners found this concept to be unfair. The positive sight of this doctrine is that it recognizes the varieties of children maturity so that even if child reaches age of formal, numerical maturity, in the reality can be defended with the argumentation that is still not mature enough and is incapable of being guilty.

This doctrine became part of Common Law system in $14^{\text {th }}$ century and the reign of King Edward the III. According to Crofts (2003), the basics of this doctrine are well explained in 1619 by Dalton in County Justice, by these words:

"An infant of eight years of age or above, may commit Homicide ..., and shall be hanged for it, viz. if it may appear (by hiding of the person slain, by excusing it, or by any other act) that he had knowledge of good and evil, and of the peril and danger of that offence. But an infant of such tender years, as that he hath no discretion or intelligence, if he kills a man, that is no felony in him".

Even though this doctrine has deep historical roots in Common Law, UK abolished it in 1997. Some of arguments for abolition of this concept were the fact that this defence couldn't be used if a minor plead guilty. So, many called this presumption ineffective and even to be „medieval law“(Wishart, 2013, p. 58). Moreover, Urbas (2000, p. 4) finds this doctrine illogical, because the criminal responsibility of a child can be rebutted by evidence that the child was of normal mental capacity for his/her age, so that might bring us to the conclusion that every child is initially proved not to be normal.

In Sharia Law, the MACR is related to reaching the age of maturity which is actually equivalent with the age of reaching puberty. When reaching into puberty one is found to be biologically mature and adult, so acquires all the legal rights and responsibilities. Puberty can be determined in two ways. According to Ćorović and Garnić (2016, p. 52), first of them are natural signs of maturity: "pollution (Ihtilan) with man and period (haiz) with woman". The other one is "the age of life" (Ćorović and Granić, 2016, p. 52). According to Sharia Law, girls get mature faster than boys, so lower ages of MACR for girls than for boys had been provided. Basically, minimum age limit of criminal responsibility is different for each sex. The minimum age of entrance in puberty differs from one Sharia legal school 
to another. In Shia, it is 9 lunar years ( 8 years and 9 months) for girls and 15 lunar years (14 years and 7 months) for boys (Nayyeri, 2016). Sunnis accept 9 years for a girl to enter in puberty, Hanbali found age of 10 to be limit for man, Hanafi found 12 years of age for man to be a minimum age. However, proving maturity even before the aforementioned ages is possible if the physical signs of reaching into puberty would appear. Since puberty is individual bio-psychological process, if the signs of puberty would appear earlier than from above mentioned ages, that person would be also found to be mature.

\section{Review of international documents regarding minimum age limit of criminal responsibility}

General international sources** $^{* *}$ of juvenile justice deal with the status of juveniles in general sense; by guarantee them protection of main human rights and separated and special treatment from adults. In other hand, in special international sources of juvenile justice there are strict provisions that deal with legal status of minors in judicial system. One of very important aspects of that topic is the matter of minimum age limit of criminal responsibility (MACR). Convention on the Rights of the Child ${ }^{* * *}$, United Nations Standard Minimum Rules for the Administration of Juvenile Justice*** and General Comment No. 10 of Committee of the Rights of the Child ${ }^{* * * * *}$ are crucial international documents that deal widely with the matter of minimum age limit of criminal responsibility.

\section{a) Convention on the Rights of the Child}

This Convention has established the definition of term "child". According to the Article 1 of the Convention, child is "every human being below the age of 18 years unless under the law applicable to the child, majority is attained earlier". This definition actually treats every person under the age of 18 to be a child and doesn't differ children from adolescents. Except of determination of term child, for topic of MACR is relevant Article 40 3(a), according to which each state is obliged to establish a minimum age bellow which children shall be presumed not to have the capacity to infringe the penal law. Effectively, Convention doesn't provide exact age that all the states would establish to be a minimum age bellow which children shall be presumed not to have criminal responsibility, but through general provision obliges states to establish that age by themselves.

\section{b) United Nations Standard Minimum Rules for the Administration of Juvenile Justice}

These rules, known also as Beijing Rules, went even a step forward. Still, the MACR hadn't been defined but states had been limited in prescribing it. The Beijing Rules, especially with the Rule 2.2., had confirmed the idea that law should be stable but not still. It should be given, applicable and changeable according to the necessities of real life

\footnotetext{
**Refering to Universal Declaration on Human Rights, International Covenant on Civil and Political Rights, European Convention on Human Rights.

***Adopted and opened for signature, ratification and accession by General Assembly resolution 44/25 of 20 November 1989. According to Anex 1 of Deyton Peace Agrement for Bosnia and Herzegovina, this convention is to be applied in Bosnia and Herzegovina.

****They were adopted by General Assembly resolution 40/33 of 29 November 1985 . From May $22^{\text {nd }} 1992$. Since Bosnia and Herzegovina is a member of United Nations, these Rules are concerning to Bosnia and Herzegovina as well.

$* * * * *$ The comment was given at the forty-fourth session of the Committee, regarding Children Rights in Juvenile Justice, in Geneva, in January/February 2007.
} 
and needs of a state. Each state has its own legal tradition, economic, social, political and cultural system, so the establishment of the age limit might vary from one state to another. That is the reason why the actual and fixed age limit has not been given by these rules, but only its main principle and indicators.

The main rule of the Beijing Rules is that the age would not be fixed at too low (Rule 4.1). However, the interpretation of the term "not too low" is a legal standard and might be interpreted according to each case. The exact indicators for the establishment of minimum age limit have been also given; such are emotional, mental and intellectual maturity. So, it has been given to a state the right to establish the age limit, but the establishment of it is not a pure formal process. It should be established according to the result of comprehensive scientific research on emotional, mental and intellectual maturity of one states' youth.

\section{c) General Comment No. 10 of Committee of the Rights of the Child}

Committee of the Rights of the Child, in the General Comment No. 10, Chapter C. titled "Age and children in conflict with the law", has been especially related to the issue of the minimum age of criminal responsibility (MACR). It emphasized main problems with the establishment of the minimum age, significance of the minimum age limit and gave the recommendation regarding to this topic. It has been explained that the reason for giving the clear guidance and recommendations regarding the minimum age of criminal responsibility had been the wide range of minimum ages in use (UN Committee General Comment No. 10, 2007, para. 30).

The Committee has explained the importance of establishment of minimum age limit. According to the General Comment, children who commit an offence at an age bellow that minimum would be held irresponsible in a penal law procedure and children at or above the MACR, but who are younger than 18 years, can be formally charged and subject to penal law procedures, but in that procedure the main principles of the Convention of the Right of Child would be implicated (UN Committee General Comment No. 10, 2007 , para. 32).

It was clearly said that even though the exact age as a minimum limit has not been established, but it has been only generalized that the limit shouldn't be too low, the MACR shouldn't be lower from 12 years. If so, then it "would not be internationally acceptable" (UN Committee General Comment No. 10, 2007, para. 32). The most suitable age range of MACR, according to the Committee would be 14 or 16 years because that age contributes to a juvenile justice system which is providing that "the child's human rights and legal safeguards are fully respected" (UN Committee General Comment No. 10, 2007, para. 33).

\section{Comparative review of MACR in the World}

Nowadays there are different tendencies among countries regarding reforms of minimum age limit of criminal responsibility. While some countries raise the age limit, some of them lower it. No international document imposes the exact age limit that all countries should prescribe, but only prescribes borders in setting $\mathrm{it}^{* * * * * *}$. That is why the MACR is different from state to state.

\footnotetext{
******Božićević-Grbić and Roksandić Vidlička (2011, p. 268) notice that, even if not setting the unique age limit for all countries, there are two similarities noticed in all countries: the idea that children should be treated separately from adults and the practice that young age is usually a mitigating factor.
} 
These different tendencies are result of sociological, traditional, cultural, religious and even scientific influences. For example, American Academy of Child and Adolescent Psychiatry, American Society for Adolescent Psychiatry, and American Psychiatric Association have pointed out certain facts regarding the criminal responsibility of minors. The prefrontal cortex situated in the frontal lobe of humans that is responsible for planning, anticipation of consequences, controlling impulses and is responsible for abstract thinking is under evolution until a person is about twenty-years-old (Death Penalty for Minors, 2016). This scientific finding brings into question the entire concept of punishment of minors and it is in favor to idea of raising the MACR as much it would be possible.

In other hand, some countries are lowering their MACR, with tendency of introducing children of very young age into judicial system, so that educational measures or treatment could be applied towards them. Even though Sergovia Bernabe (2001, p. 77) thinks there is "hardly overcoming divorce between criminal law and pedagogy", nevertheless the main intention of that tendency is helping minors to grow out of crime and possibility of recidivism.

The matter of establishing MACR is a responsible, more scientific than numeric action. According to Škulić (2010, p. 205), in theory there are absolute and relative approaches in establishment of MACR. While the absolute is objective and is focused only in certain number of years, the relative is the one that is based on bio-psychological development of a person. In reality, both of these approaches should be merged in establishing the basics of criminal responsibility of a minor. In Germany there are given specific criteria for establishing maturity and with that prescribing MARC such are: plans for life, independence of parents, independence of people of same age, seriousness towards obligations, external look, age of friends, involvement in love and sex, state of spirit, reality (Giménez-Salinas, 2001).

Even though it's left to every individual state to establish MACR, and even though there are different socio-cultural-traditional backgrounds in states, there have been informally established classes of MACR. According to Cipriani $(2009$, p. 113, 118) 55 countries of the World are applying presumption doli incapax and 75 countries in the World are using the classical MACR. In the USA, 15 states have established MACR with age range 6-10 years and in the remaining states there is no minimum established at all.

\begin{tabular}{|c|l|}
\hline MACR & \multicolumn{1}{|c|}{ State } \\
\hline 7 years & $\begin{array}{l}\text { Brunei, Egypt, Estonia, Grenada, India, Jordan, Kuwait, Lebanon, Leso- } \\
\text { tho, Liberia, Malawi, Mauritania, Myanmar, Namibia }\end{array}$ \\
\hline 8 years & Botswana, Indonesia, Kenya \\
\hline 9 years & Bangladesh, Ethiopia, Sharia Law states (girls), Malta, \\
\hline 10 years & $\begin{array}{l}\text { Australia, Bhutan Cameroon, Fiji, Ireland, England and Wales, Northern } \\
\text { Ireland }\end{array}$ \\
\hline 11 years & Barbados, Japan \\
\hline 12 years & $\begin{array}{l}\text { Afghanistan, Andorra, Angola, Belgium, Brazil, Canada, Costa Rica, } \\
\text { Dominica, Ecuador, Georgia, Ghana, Israel, Turkey, Mexico, Morocco, } \\
\text { Netherlands }\end{array}$ \\
\hline
\end{tabular}




\begin{tabular}{|c|l|}
\hline 13 years & France, Chad, Gambia, Mali, Greece \\
\hline 14 years & $\begin{array}{l}\text { Austria, Germany, Italy, EU Countries, Bosnia and Herzegovina, Serbia, } \\
\text { Croatia, Montenegro, Macedonia }\end{array}$ \\
\hline 15 years & Denmark, Finland, Iceland, Norway, Sweden \\
\hline 16 years & Portugal, Spain, Ukraine, China \\
\hline
\end{tabular}

* Review of MACR in several countries of the World (Cipriani, 2009, pp. 98-106; Minimum Ages of Criminal Responsibility in Europe)

As it is shown in the table above, most of the European countries set MACR at 14 years. Some of them set even higher MACR, which shows the determination of states from European continent in high MACR. The exception would be Estonia with very low MACR for European standards. In other hand, most of South American states determined MACR at the age 12. African countries show tendency of establishing low MACR. Asian states as well have low MACR.

Cipriani (2009, p. 112) emphasizes the fact that in the last two decades 40 countries increased their MARC (such are UK, Canada, Panama, Ecuador, Mexico, and Lebanon). But, that tendency is not present in the entire World. Countries such are France, Nepal, and Mauritania decreased the MACR. Jimenes Diaz $(2015$, p. 2) claims that the main reason for lowering the MACR is high fear of juveniles' crime. Public pressure that is led by fear of crime makes the limits of MACR to move down. For example, there is highly discriminatory proposal in Germany on lowering MACR to 12 years only to migrant children, since the there were several cases of crimes perpetrated by migrants' youth (Jiménez Díaz, 2015, p. 121).

\section{MACR in Bosnia and Herzegovina}

With the aim to determine whether there were significant differences in regulation of MACR in different periods of criminal law in Bosnia and Herzegovina and in relation to contemporary regulation of MACR in the World, it is necessary to make a historical review and a review of positive law in Bosnia and Herzegovina regarding MACR. Historical review includes analysis of provision related to the MACR according to the Criminal Code of Federative People's Republic of Yugoslavia (1947), Criminal Code of Federative People's Republic of Yugoslavia (1951), Criminal Code of Socialistic Federative Republic of Yugoslavia (1976), Criminal Code of Federation of Bosnia and Herzegovina (1998), Criminal Code of Republika Srpska (2000) and Criminal Code of Brčko District of Bosnia and Herzegovina (2000).

Related to positive law, from year 2003 until 2010 (Republika Srpska and Brčko District and year 2014 regarding Federation of Bosnia and Herzegovina) Criminal Code had been applied as the main positive source of criminal law related to legal status of juveniles in conflict with law. Since then, positive juveniles' criminal law include three laws on protection and dealing with children and adolescences in Criminal Procedure that had been given in Federation of Bosnia and Herzegovina, Republika Srpska and Brčko District. By applying the rule that special law derogates general law (lex specialis derogat legi 
generali), the special $\operatorname{codes}^{* * * * * *}$ are to be applied instead of the general code (Criminal Code). The exception has been made with the Criminal Code of Bosnia and Herzegovina (CC BH). Since on States' level of authority special law that is related to issues of juvenile justice hadn't been adopted, at that level of authority in Bosnia and Herzegovina, general law is still applying (Criminal Code of Bosnia and Herzegovina).

\section{Historical review of MACR in Bosnia and Herzegovina}

Criminal Code of Federative People's Republic of Yugoslavia (further in text: CC FPRY) had established the MACR on age of 14 years. According to that Code, any person who was under that age was criminally irresponsible (CC FPRY, 1947, art. 7(1)). However, this Code hadn't only prescribed the MACR, but acknowledged the fact that even though people younger than 14 are criminally irresponsible, with their formal criminal act they actually step into criminal zone and in that way they show their possible predisposition of perpetrating crimes in the future. So, general approach of that time was that society mustn't ignore that predisposition and has to prevent their future recidivism. To accomplish that, it had been prescribed that the offender would be given to parents or guardianship office so they could apply educational measures on that person or he/she would be sent into the educational institution (CC FPRY, 1947, art. 7(2)). So even though people under age of 14 were criminally irresponsible, family or specific institution had to apply educational measures so that in that way the sources of their criminality would be abolished.

Exception of criminal punishment had been given also in the article 8. of CC FPRY and it excluded punishment of persons older than 14 years of age, who in the moment of the perpetration of the crime were not aware of the meaning of the action and who couldn't conduct with its actions. Those persons were criminally irresponsible and not punishable and that was regulated according to the basic concepts of Criminal Law, because in their act there was no subjective side. Yet, towards those persons educational measures had to be applied.

Persons older than 14 years had been criminally responsible and all legal sanctions except of the death penalty and imprisonment with lifelong forced labor could have been imposed (CC FPRY, 1947, art. 9(1)). In the choice of the appropriate sanction, court had to especially take in count the level of psychological development of that person. The court was entitled to impose only educational measures towards the adolescent if it would be established that according to the personal characteristics of the perpetrator and the circumstances of the case, it wouldn't be needed to impose penalty, and if the adolescent was older than 14 years of age but younger than 16 years of age (CC FPRY, 1947, art. 9(2)). The aim of this possibility was to prevent the person who was not fully physically and psychologically mature, from reaching into the system of punishments that would label that adolescent as convicted person for lifetime.

The same MACR had been established in the Criminal Code of Federative People's

$\star * * * * * *$ Those are: Law on protection and dealing with children and adolescences in Criminal Procedure (in Federation Bosnia and Herzegovina; further in text: Children and Adolescents Code FBH), Law on protection and dealing with children and adolescences in Criminal Procedure (in Republika Srpska; further in text: Children and Adolescents Code RS) and Law on protection and dealing with children and adolescences in Criminal Procedure (in Brcko District BH; further in text: Children and Adolescents Code BDBH). 
Republic of Yugoslavia (further in text CC FPRYa), since person who hadn't been 14 years old in the moment of perpetration of the crime, was criminally irresponsible (CC FPRYa, 1951, art. 5(1)). Just like according to the previous Code, court could set educational measures towards that person.

The fact that one person was 14 years old in the moment of perpetration of crime hadn't been the guaranty that will be held criminally responsible. According to the Article 5(2) of this Code, if adolescent couldn't understood the importance of his act and control his actions due to his psychological underdevelopment, that person had been criminally irresponsible. This leads to the conclusion that criminal responsibility of adolescents who were 14 years old was being determined in each case separately, which is quite according to general concept of criminal responsibility in Criminal Law. Without mental competence there is no criminal responsibility. This Code also provided classification of adolescents into younger and older adolescents; younger ones were older than 14 years of age, but younger than 16. Adolescents older than 16 years of age were older adolescents. Both of them were criminally responsible but the main difference in their legal status was the type of criminal sanction that could have been imposed (CC FPRYa, 1951, art. 67 and 71).

Criminal responsibility of persons younger from 14 years of age was excluded as well in Criminal Code of Socialistic Federative Republic of Yugoslavia (further in text CC SFRY). This Code had indirectly defined a child to be a person who in the moment of perpetration of crime hadn't been 14 years old (CC SFRY, 1976, art. 72). Adolescents had been classified in two groups, but with some differences from the regulation with the previous Code. Younger adolescent was a person who was 14 but not 15 years old, and older adolescent was a person who was 15 but not 18 years old. So, the main difference from previous codes and this one was in the age limit that differs younger from older adolescents.

Newer history of Bosnian and Herzegovinian criminal law had been established from 1998 (with Criminal Code in Federation of Bosnia and Herzegovina) and 2000 (with Criminal Code of Republika Srpska and Criminal Code of Brčko District). From dissolution of SFRY until these years, criminal law from SFRY had been applying. These three codes had the same regulation of MACR and classification of adolescents. Indirectly, just like CC SFRY, all three of them had defined "child" to be a person who was not 14 years old (Criminal Code of Federation of Bosnia and Herzegovina, 1998, art. 71; Criminal Code of Republika Srpska, 2000, art. 67; Criminal Code of Brčko District BH, 2000, art. 71). The criminal punishability was excluded for children. Adolescents were persons who were 14 years old, they were punishable. Classification of adolescents had been made and there were differed younger (14-16 years of age) and older (16-18 years of age) adolescents. So basically, the same tradition in establishing MACR had been continued.

\section{MACR according to positive law in Bosnia and Herzegovina}

Even though there are three different laws on protection and dealing with children and adolescences in Criminal Procedure in Bosnia and Herzegovina, that had been given at three states authorities (Federation of Bosnia and Herzegovina, Republika Srpska and Brčko Distrikt BH), and have some differences in providing legal status of juveniles, regarding the matter or MACR their provisions are harmonized. All three of them define who is a child, who is an adolescent and classify adolescents. 
According to positive special laws on protection and dealing with children and adolescences in Criminal Procedure in Federation of Bosnia and Herzegovina, Republika Srpska and Brčko District $\mathrm{BH}$, the minimum age limit for criminal responsibility has been established at 14 years of age (Children and Adolescents Code FBH, 2014, art. 2(2); Children and Adolescents Code RS, 2010, 2(2); Children and Adolescents Code BDBH, 2010, art. 2 (2)). Persons who were not 14 years old in the moment of perpetration of the crime can't be sanctioned. In other hand, all three laws gave a definition of a term "child" in a way that child is every person who is not 18 years old (Children and Adolescents Code FBH, 2014, art. 2(1); Children and Adolescents Code RS, 2010, 2(1); Children and Adolescents Code BDBH, 2010, art. 2 (1)).

Furthermore, the definition of a term "adolescent" had been also given. That is a person who in a moment of a crime perpetration was 14 years old, but was not 18 years old (Children and Adolescents Code FBH, 2014, art. 2(3); Children and Adolescents Code RS, 2010, 2(3); Children and Adolescents Code BDBH, 2010, art. 2 (3)).

According to leges speciales, all adolescents are children, and the term "child" is prescribed widely in comparation to a term "adolescents". Adolescents can be sanctioned. By all three laws, there are two groups of adolescents: younger adolescents and older adolescents. Younger adolescents are persons who were 14 years old but not 16 years old in a moment of perpetration of the crime. Only educational measures can be imposed to them. In other hand, persons who were 16 years old, but not 18 years old in the moment of perpetration of the crime are older adolescents Children and Adolescents Code FBH, 2014, art. 3(1) and 3(2); Children and Adolescents Code RS, 2010, 3(1) and 3(2); Children and Adolescents Code BDBH, 2010, art. 3(1) and 3(2)). They can be sentenced to educational measures, but in certain cases they can be punished with juvenile imprisonment. Both groups however can be sanctioned with security measures as well.

Related to lex generalis that is still applying at the States level of authority, it also provides MACR, through definition of term "child" and "adolescent", differs groups of adolescents, but all that with certain differences from leges speciales.

Even though this Code gives the same MACR as the special codes, it prescribes different definition of a term "child", by defining that a child is a person who is not 14 years old (Criminal Code of Bosnia and Herzegovina, 2003, art. 2(11)). This definition is different from the definition of a term "child" according to the Convention on the Rights of Child as well. If the grammatical interpretation of this provision and those in leges speciales is used, then the one given by the $\mathrm{CC} \mathrm{BiH}$ is narrower, since person from 14 to 18 years is not a child. According to provision of Article 2 (12) of CC BiH that person is adolescent, because it's not 18 years old. The States' Criminal Code has the same provisions regarding to the classification of adolescents and their sanctioning as leges speciales have (Criminal Code of Bosnia and Herzegovina, 2003, art. 80 (2) and 80 (3)).

\section{Conclusion}

The position of the child in Criminal Law is specific. No matter being victim or the perpetrator, children are specific and sensitive category determined with their psychological and physical (in)maturity (Horvatić, Derenčinović and Cvitanović, 2016).

The question of maturity that can lead to conclusion that somebody is responsible and guilty for the committing of a criminal act is an individual matter. Decision of establishing 
MACR is an intention of diverting individual state of mind to a general rule. That is why that topic is so challenging. It is quite understandable that marking MACR is not a numerical function but numerical result of systematic sociological, pedagogical and psychological estimations. That is also one of the reasons why international documents don't prescribe exact number for MACR, but leave to the states to decide about it. In other hand, Committee of Right of the Child clearly recommended the border of MACR to be 14 or 16 years. In the comparative analysis it is to be seen that there are different MACRS prescribed in the World and that states which are linked by geographical, historical or legal system similarities prescribe the same/similar MACR. It's obvious that there are different politics regarding lowering or increasing the border for MACR, even though there are clear recommendations given regarding MACR, states decide to decrease it bellow the recommended age.

Even though the true reason for decreasing the MACR in several states is in fact the fear of crime of minors and commitment of those states in not ignoring the fact that even younger persons in reality commit very serious crimes, so that lowering the limit would make them criminally responsible and involved in criminal law (justice) system. This idea, observed from the surface, it can seem like it is something not according with the modern criminal law perspective towards minors, that consists of finding the best treatment for them instead of punishing them. But, this politics might be the exact product of that perspective. If a child commits a crime it shows possible propensity in committing crimes in future and that should be understood as an alarm because the offence itself can be a sign of a need for treatment.

Punishment is not anymore the most used legal sanction, but there is wide choice of educational and protective measures that can be imposed on minor and divertive procedures that neutralize the problem of conviction labels. So, if only divertive procedures and alternative measures would be used towards very young minors, then the intention of decreasing MACR wouldn't be undesirable, nor the wrong path. In that way the suitable treatment would be provided for children so their recidivism might be prevented. However, this conclusion has its limitations since some countries in the world still don't use principles of restorative justice towards minors, but find punishment to be the most successful and useful legal sanction. There, inclusion of children in criminal and penal system might have negative effect in their future life. Furthermore, in contemporary criminal law, social factors are recognized as one of the main causes for criminal activity of the minors, which leads to the clear conclusion that, to solve this "problem", prevention needs to play most important role, not the criminal sanction applied only after the criminal offence is committed (see National Research Council and Institute of Medicine, 2001, 107). In accordance to that, some European countries, respecting the fact that the child is a person under the age of 18 years, and, although drawing the line on 14 years of the age border, provides the possibility that Criminal code will not be applicable if the special code for minors provides differently (Criminal Code of Croatia, „Narodne novine“ No. 25/11).

In Bosnia and Herzegovina MACR didn't suffer through any changes in time. The constant minimum age of criminal responsibility was and still is 14 years of age. With the exception of the provisions of CC SFRY, even the border in distinction between younger and older adolescents remained the same through ages. Yet, in new, special codes that refer 
the protection and dealing with children and adolescences in Criminal Procedure the term child got different meaning which is different from the meaning provided in Criminal Code of Bosnia and Herzegovina. Without any doubt, different regulation of the same thing in one country is impermissible because legal position of a child in the territory of one state should be the same and that refers to understanding of term child as well. In this way, Bosnia and Herzegovina and its legal system, don't respect basic principle in treatment of the children: its best interest, neglecting the fact that those children are its future.

\section{References}

Božićević-Grbić, Melita and Roksandić Vidlička, Sunčana. (2011). Reforma maloljetničkog kaznenog prava i sudovanja. Hrvatski ljetopis za kazneno pravo i praksu , 18 (2), Zagreb;

Bryan-Hancock, Claire and Casey, Sharon. (2011). Young people and the Justice System: Consideration of Maturity in Criminal Responsibility. Psychiatry, Psychology and Law, 18 (1). Routledge;

Cipriani, Don. (2009). Children's Rights and the Minimum Age of Criminal Responsibility - A Global Perspective. Routledge.

Convention on the Rights of the Child. (1989).

Criminal Code of Republika Srpska. (2000). Official Gazette of Republika Srpska, No. 22/00, 37/01; Criminal Code of Socialistic Federative Republic of Yugoslavia. (1976). Official Gazette of Socialistic Federative Republic of Yugoslavia, No. 44/76, 36/77, 34/84, 37/84, 74/87, 57/89, 3/90, 38/90, 45/90, 54/90, 35/92;

Criminal Code of Bosnia and Herzegovina. (2003). Official Gazette of Bosnia and Herzegovina, No. 3/03, 32/03, 37/03, 54/04, 61/04, 30/05, 53/06, 55/06, 32/07,8/10, 47/14;

Criminal Code of Brčko District BH. (2000). Official Gazette of BD BH, No. 6/00, 1/01, 3/03;

Criminal Code of Croatia. (2011). Narodne novine, No. 25/11);

Criminal Code of Federation of Bosnia and Herzegovina. (1998). Official Gazette of Federation Bosnia and Herzegovina, No. 43/98;

Criminal Code of Federative People's Republic of Yugoslavia. (1947). Official Gazette of FPRY, No. 106/47;

Criminal Code of Federative People's Republic of Yugoslavia. (1951). Official Gazette of FPRY, No. 13/51, 30/59;

Crofts, T. (2003). Doli Incapax: Why children deserve their protection. Murdock University Electronic Journal of Law, 10/3. Retrieved o 01.12.2016, from http://www.austlii.edu.au/au/journals/MurUEJL/2003/26.html;

Ćorović, Emir and Ganić, Senad. (2016). Osnovne karakteristike šerijatskog krivičnog prava u poređenju sa dominantnim krivičnopravnim sistemima. Strani pravni život (3), Belgrade;

Death Penalty for Minors. Retrieved on 01.12.2016., from: https://deathpenalty.uslegal.com/minors/death-penalty-for-minors/;

Elliott, Catherine. (2011). Criminal Responsibility and Children: A New Defence Required to Acknowledge the Absence of Capacity and Choice. The Journal of Criminal Law.

Fagan, Jeffrey. (2000). The Changing Borders of Juvenile Justice: Transfer of Adolescents to the Criminal Court. University of Chicago Press;

Giménez-Salinas, Esther. (2001). Principios orientadores de la resopnsabilidad penal de los menores. Responsabilidad penalde los menores:una respuesta desde los derechos humanos in Collection «Jornadas sobre derechos humanos». San Santiago: Artateko;

Horvatić, Željko, Derenčinović, Davor and Leo Cvitanović (2016). Kazneno pravo, opći dio prvi dio; Pravni fakultet Sveučilišta u Zagrebu;

Howard, Helen and Bowen, Michael. (2011). Unfitness to Plead and the Overlap with Doli In- 
capax: An examination of the Law Commission's Propsals for a New Capacity Test. The Journal of Criminal Law. Sage Publications;

Jiménez Díaz, Maria Jose. (2015). Algunas reflexiones sobra la responsabilidad penal de los menores. Revista Electrónica de Ciencia Penal y Criminología. No. 17-19;

Law on protection and dealing with children and adolescences in Criminal Procedure. (2010). Official Gazette of Republika Srpska, No. 13/10, 61/13;

Law on protection and dealing with children and adolescences in Criminal Procedure. (2010). Official Gazette of District Brčko of Bosnia and Herzegovina, No. 2/10, 44/11;

Law on protection and dealing with children and adolescences in Criminal Procedure. (2014). Official Gazette of Federation Bosnia and Herzegovina, No. 7/14;

National Research Council and Institute for Medicine. (2001). Juvenile Crime, Juvenile Justice; Panel on Juvenile Crime: Prevention, Treatment. Control Committee on Law and Justice;

Minimum Ages of Criminal Responsibility in Europe. Retrieved on 01.12.2016. from https://www. crin.org/en/home/ages/europe;

Nayyeri, M. H. Criminal Responsibility of Children in the Islamic Republic of Iran's New Penal Code. Retrieved on 01.12.2016. from http://www.iranhrdc.org/english/publications/ legal-commentary/1000000054-criminal-responsibility-of-children-in-the-islamic-republic-of-irans-new-penal-code.html.;

Richards, K. (2011). What makes juvenile offenders different from adult offenders? Trends \& issues in crime and criminal justice. No. 409. Australian Government and Australian Institute for Criminology;

Segovia Bernabé, J. L. Responsabilidad penal de los menores: una respuesta desde los derechos humanos. Responsabilidad penal de los menores: una respuesta des de los derechos humanos;Collection «Jornadas sobre derechos humanos». No. 5. San Santiago: Artateko (2001);

Škulić, Milan. (2010). Starosna granica sposobnosti za snošenje krivice u krivičnopravnom smislu, Crimen , 1 (2);

UN Committee General Comment No. 10. (2007);

United Nations Standard Minimum Rules for the Administration of Juvenile Justice - "The Beijing Rules". (1985);

Urbas, G. (2000). The Age of Criminal Responsibility ;. Trends \& issues in crime and criminal justice. No. 181. Australian Government and Australian Institute for Criminology;

Wishart, H. (2013). Was the abolition of the doctrine of Doli Incapax necessary?. UK Law student Review, 1 (2). 